\title{
INNOVATIVENESS OF DIDACTIC PRACTICE IN THE FIELD OF CURRENT PEDAGOGICAL KNOWLEDGE
}

\author{
Tomasz Prauzner \\ Department of Pedagogy, \\ Jan Dlugosz University in Czestochowa, Poland
}

\begin{abstract}
The theory of education, which is didactics, in the realities of today's educational practice and upbringing is becoming more important in the work of a teacher. The theory of education is improving thanks to newer empirical knowledge created on innovative practice. Currently, there is a traditional division of education theory into general, specific, environmental and special didactics. However, in terms of new teaching aids and brain research methods, it is worth considering its new meaning.
\end{abstract}

Keywords: educational theory, didactics, constructivism, electroencephalographic research

\section{Introduction}

The article will present considerations regarding the development of present main didactic in connection with the development of detailed didactics. Detailed didactics set a new teaching trend using modern teaching aids (Prauzner, 2017a). The theme is extremely extensive, and this work will present only selected problems associated with the emergence of modern teaching. The conclusions resulting from the author's research presented in the references prove that modern didactic aids, especially in the field of technical education, influence didactic efficiency. Teaching effectiveness can also be assessed by QEEG electroencephalographic tests.

Didactics is the science of education and self-education. The name "didactics" comes from the Greek language, in which "didaktikos" means "informative" and "didasko" - "teach" (Bereźnicki, 2007, p. 13). The turn of the 19th and 20th centuries influenced by the slogans of the "new school" proclaimed, among others, by John Dewey (1859-1952), brings ideas of active learning through action. Supporters of this field have highlighted the activities of students and focused on their creative role in the learning process (Bereźnicki, 2007, p. 15). The theory of education meets the requirements of scientific theories, has its own scope of research and research methods specific to it, which allows enriching the theory and verifying innovative proprietary propositions, as well as assessing common teaching practice. Didactics is a theoretical science that defines known educational models and at the same time sets new practical trends (studies the 
Prauzner, 2020. Innovativeness of Didactic Practice in the Field of Current

Pedagogical Knowledge

intentional behavior of teachers and students) (Juszczyk, 2008). Therefore, any attempt to present didactics as a theoretical proposal with indications of innovation in teaching practice becomes particularly desirable during the period of reconstruction and improvement of the education system, which changes in accordance with current socio-economic needs and challenges.

\section{The importance of detailed didactics in developing one's own cognitive activity}

Didactics in the Polish Language Dictionary edited by Witold Doroszewski has two meanings: 1) pedagogy section dealing with teaching methods; 2) instructing, moralizing. Didactics examine general issues related to the teaching attitudes of all subjects, detailed didactics also called methodology, deals with specific issues of teaching a selected subject or group of subjects (...). Didactics deals with the study of the purposes and content of education (learning and teaching); didactics is praxeological - it is a important theory of effective teaching. Didactics is tackling the problems concern the purposes, content and methods of teaching (Doroszewski, 1966, p. 482).

Modern didactics helps teachers to constantly improve their teaching skills and enrich teaching practices and organize students' cognitive activity. It seems right dictum that knowledge of reality should stimulate us to innovation, which is intended to eliminate unnecessary and incorrect didactics phenomena. Innovation will be more essential the better that our experience about current problems in the broadly understood education system will be experienced. Right and effective education depends primarily on the knowledge and use of modern didactics. Modern didactics should be understood as innovation in practical activity adequate to current social needs. Therefore innovation and all kinds of school reforms seem to be a continuous process.

This problem in the field of general didactics has been dealt with and dealt with for many years by such great educators of Polish science as: Bogdan Nawroczyński, Kazimierz Sośnicki, Zygmunt Mysłakowski, Lucjan Zarzecki, Sergiusz Hessen and then Wincenty Okoń, Władysław Piotr Zaczyński, Tadeusz Lewowicki, Czesława Kupisiewicz, Kazimierz Denek and Franciszek Bereźnicki, Stanisław Palka et al. (Półturzycki, 1999, p. 8). Of course, in the field of detailed didactics, names such as Tadeusz Nowacki, Zygmunt Wiatrowski and others are not foreign to the polish reader. The current theory of teaching goes back to ever newer fields of knowledge, an example of which is the more widely discussed neurodidactics, whose representative in the world of science can be M. Spitzer and M. Żylińska.

Półturzycki note special attention to the teacher's awareness of the realization of the set educational purpose through the implementation of proper conduct in 
the implementation of the lesson as the basic form and control, and assessment of learning outcomes (Op. Cit., p. 9). Modern didactics is also an attempt to change the consciousness of the student himself in undertaking actions based on selfeducation and thus developing his own cognitive activity. In academic education, the process of self-education is often the basic mode of learning, based primarily on the search for knowledge and the acquisition of skills by all methods.

The role of the teacher changes its functional meaning from a serving attitude to an attitude in which the teacher is only a guide of the student through current knowledge resources. Modern information technologies, which are the basic tool of modern didactics, support this relationship. One of the basic roles of a teacher is currently introducing innovation by enriching the teaching methods used, for example, using modern teaching aids. Wincenty Okon, in the "Introduction to General Didactics", writes that didactic aids "... effectively help to transform the traditional system into a modern teaching and learning process that activates students.”

Didactics studies the aims and content of general, polytechnic, vocational education and the conditions of teaching. General didactics deals with the problems of teaching all subjects, while detailed didactics (methodology) refers to specific subjects of teaching. It should be mentioned that the main problems of general didactics very often result from the problems of detailed didactics, in which the education methodology provides the most important data and problems of modern education, e.g. media. A new aspect at general didactics is the result of innovation in the field of detailed didactics.

J. Półturzycki aptly expressed idea in his words (after Zaczyński, 1993): the field of interest in the theory of general education has been changed with the emergence of modern scientific aids. General didactics deals with the educational process, including: didactic purpose, content and methods, means and organization of education, as well as researching the social and material environment in which this activity takes place. The theory of general education establishes the causal relationship between the work of the teacher and the work of students and seeks such methods that will guarantee the correct and most effective effect of education. The theory of general education has, among other things, a diagnostic function, and thus provides information on a given state of affairs, not always only positive but very often negative with a common ground resulting from problems dealt with in other fields of social, humanistic or technical sciences. Thanks to this, it also informs us about negative aspects and gives tips on how to remedy them (prognostic function). He deals with methods, means and conditions for the implementation of teaching objectives, and also has an instrumental and technical function.

In the era of the development of the information society, based on the use of modern technologies, general didactics strictly reaches for innovative 
instrumental solutions. The subject of teaching is, inter alia, the study of teaching aids and optimization of the conditions for their effective use in education (Półturzycki, 1993, p. 134). The author emphasizes that the division of didactics into general and specific (as well as specific types of education, environmental and specialized) loses its relevance, while it emphasizes the fact that this division in terms of current didactic problems becomes problematic and the important role of scientific publications of the nature is emphasized mixed - environmental and specialist.

In the author's assessment, the perspective on modern theory of general education takes on an important aspect. The theory changes in its general canons quite slowly, while faster changes occur in theories and subject matter as well as the sciences interacting on it. J. Półturzycki emphasizes the fact that this necessitates the systematic improvement and development of educational practice. Didactics is science and skill at the same time, and to master one more thoroughly, it is not enough just academic knowledge but above all educational practice is necessary. Modern teaching aids based on information and information technology are an indispensable element of the theory of general education, supporting the process of learning and thus determining the effectiveness of education (Bruce, Calhoun, \& Hopkins, 2010). Modern teaching aids are introduced at virtually all levels of education. We can read about many problems of their use in modern didactics in numerous scientific publications on this subject (Prensky, 2001; Palloff, 2007; Collins, 2009). Pedagogy as a science of education and teaching, belongs to social sciences and deals with the development and change of mechanisms of upbringing and education throughout all the human life (Brown, 2019; Carr, 2011). The theory of general education as a subdiscipline of pedagogy is a response to current problems of upbringing and education of the young generation in the age of digitization of the world. Literature emphasizes the essence of knowledge passed on by practising teachers in various forms of improvement for general education, because it is thanks to teachers and lecturers that didactics is able to developing. It is their experience transmitted, for example, through the media and reports on the effectiveness of general education, highlights educational problems, that are often invisible to the general public and remain in the shadow of interest. J. Półturzycki emphasizes that "own educational practice gradually clarifies the principles and problems of didactics, allows them to better understand and implement them in the self-organized didactic process." (Półturzycki, 1999, p. 31).

The object of research explaining the reason for the existence of pedagogy as a science is educational practice, which consists of many phenomena, such as the operation of educational institutions, interpersonal relations prevailing in them, changes occurring in people subjected to educational effects, etc. Pedagogy exists regardless of the intentions and actions of scholars. Their task, however, is 
to describe this practice, explain phenomena that destabilize educational activities, discover the results to which education leads (Kwieciński \& Śliwerski, 2004, p. 18). For the author, the above words are a determinant of practical activities within pedagogy as a science, including about education. Who, if not a teacher or lecturer, receives examples of this in his professional work? The educator is the first person and nearest to the student in the didactic process. It is he who implements the objectives of formal education from above, he is the one who feels the most effects of his professional work - the author recalls.

On the other hand, his attitude is also an indicator of didactic progress, which is an extremely dynamic process which is also the result of all socio-economic changes of a global nature. The evaluation of didactic practice provides researchers with new hints as to the validity of innovations introduced in the education process. That is why observation of the educational environment, its analysis of activities, and measurement of work effects through the prism of social and economic needs are so important. Consequently, the education of a society based on modern educational practice in accordance with accepted standards in the sociological perspective is the level of national culture and thus its impact on the harmonic flourish of other scientific subdisciplines. It is an indicator of the progress of civilization, a place in the scientific and cultural achievements of the world and a guarantor of order in the world. Failure to care for the development of science and the level of education found its place in the history of each nation. Educational practice is diverse in many ways (it researches, among others, the educational impact of the media, popular culture, family, peer groups), and pedagogy is the science describing this practice, this diversity of pedagogy must reflect the state of education. This is also because the degree of specialization of scientific knowledge in specific education contexts requires scholars of diverse cognitive competences to study them. Thus, pedagogy is a field composed of many scientific sub-disciplines dealing with various areas of educational practice (Rubacha, 2004, p. 21).

Pedagogy deals with identifying, naming and defining all the facts that make up the practice of education (Op. Cit., p. 24). In terms of the practice of pedagogical research “... a qualitative researcher has a special opportunity to learn not only the facts, educational events, but also the circumstances in which they took place, the effects they caused, and the meanings that people gave them. What's more, he observes the same facts from different perspectives: from the point of view of a good, weak student or teacher." (Op. Cit., p. 34-35). 
Prauzner, 2020. Innovativeness of Didactic Practice in the Field of Current Pedagogical Knowledge

\section{Concluding remarks}

The effectiveness of education is the result of implemented innovations in the education process. The selection of appropriate teaching methods and teaching aids determines the student's cognitive activity during the teaching classes. The teacher's many years of experience are conducive to the organization of lessons. Cognitive activity can be assessed not only by assessing work, but also accurately observed, for example, by using modern observation methods thanks to electroencephalogical research such as EEG and QEEG. The examples are interesting conclusions obtained by the author in the field of detailed didactics in the technique and related fields (Prauzner et al., 2019; Prauzner et al., 2018). Detailed conclusions were included in numerous author's publications, which clearly indicate that the use of multimedia teaching aids on the basis of deterministic computer simulations programs are important in shaping the student's active attitude in the teaching process (Prauzner, 2010; 2013). Therefore, innovation in teaching is a multidimensional element and requires great diligence on the part of not only the teacher himself but also the continuous shaping of the correct attitude and commitment of the student himself in the teaching process.

The overriding object of each teaching process is, therefore, optimal mental, emotional and volitional development of the student, i.e., all conscious, planned and systematic didactic and educational interactions ensuring general or vocational education (Kupisiewicz, 2005). In the problem task, the most important method, from the point of technical education, not only basic mental and motor operations are involved, but also other activities less related to the task (Prauzner, 2015a; 2015b). Further tasks appearing in life are then solved in the same way through acquired behaviors and reactions. In addition, if the reactions are accompanied by a feeling of satisfaction, and therefore positive feelings, then the acquisition of these skills will be easier and fixed for a longer period, otherwise the degree of solution the problem will be more difficult (Półturzycki, 1999). In this field, importance of modern teaching aids in the teaching process becomes extremely important. As emphasized by J. Pólturzycki, the learning process is also diversified by the individual abilities of the student, often appearing as factors independent of the teacher's and the teacher's intentional actions. Their cause is seen in biological and psychological development shaped under the influence of the surrounding local environment. The local environment for the student is a family environment but above all the school itself. The school (college) understood formally as an educational institution, but also in a more social perspective as a peer group.

Modern didactics is an empirical and analytical science dealing with the description and explanation of facts, phenomena and processes occurring in school and social reality. The above theoretical considerations regarding the field 
of influence of didactic practice induce the reader to further reflection (Prauzner, 2018). The importance of specific didactics in solving problems of general didactics, is invaluable to indicate the specific problems faced by modern education.

A thorough analysis of the topic has been included in the published scientific monography and papers (Prauzner, 2016a; 2016b; 2017b). The publish presents research on the importance and role of modern simulation programs in technical education (Ptak, 2016; Ptak \& Prauzner, 2019). The main area of research has been included in a number of problem questions:

Does and to what extent the use of deterministic computer simulations (DSK) develop students' creative thinking in the field of cognitive ability in technical education?

Does and to what extent does the use of DSK develop students' technical imagination in the field of cognitive skills in the field of technical education?

Is the use of DSK conducive to understanding physical phenomena occurring within the analyzed technical problem on the basis of the models made and simulating their operation in the field of cognitive ability in the field of technical education?

Is the knowledge of manual of DSK conducive to shaping the ability to solve professional problems?

To what extent do DSK affect the resource and acquisition of new technical knowledge?

Do deterministic computer simulations stimulate interest in a given field of science?

Do you think that the simulation method in which DSK was used can be considered as an activating and motivating method for further learning?

Has the acquired experience of working with DSK influenced the decisionmaking related to additional self-education in order to improve professional qualifications and competences?

In the studies have been performed statistical calculations confirming the assumed hypotheses resulting from the above questions and showing the strength of relationships between individual independent and dependent variables. All hypotheses have been accepted as true.

\section{References}

Bereźnicki, F. (2007). Dydaktyka kształcenia ogólnego. Wyd. Impuls, Kraków.

Brown, J.S. (2019). Growing Up Digital: How the Web Changes Work, Education, and the Ways People Learn. United States Distance Learning Association. Retrieved from https://eric.ed.gov

Bruce, J., Calhoun, E., \& Hopkins, D. (2010). Models of Learning, Tools for Teaching. McGraw-Hill Open University Press; 3rd edition. 
Prauzner, 2020. Innovativeness of Didactic Practice in the Field of Current

Pedagogical Knowledge

Carr, N. (2011). The Shallows: How the Internet is Changing the Way We Think, Read and Remember. Publ. Atlantic Books.

Collins, A., \& Halverson, R. (2009). Rethinking education in the age of technology. The Digital Revolution and Schooling in America. NewYork: Teachers Collage Press.

Doroszewski, W. (1966). Stownik języka polskiego. Wydawnictwo WP, Warszawa.

Juszczyk, S. (2008). Cele i założenia metodyki ksztatcenia edukacji medialnej i technologii informacyjnej. Pedagogika medialna, Wydawnictwo Naukowe UMK, Torun.

Kupisiewicz, Cz. (2005). Podstawy dydaktyki. WSiP Warszawa.

Kwieciński, Z., \& Śliwerski, B. (2004). Pedagogika. Podręcznik akademicki, Wyd.PWN, Warszawa.

Lewowicki, T. (1994). Przemiany oświaty. Szkice o ideach i praktyce edukacyjnej. Wydawnictwo WPUW, Warszawa.

Palloff, R.M., \& Pratt, K. (2007). Building Online Learning Communities. SanFrancisco: John Wiley \& Sons Inc.

Półturzycki, J. (1999). Przedmiot i zadania dydaktyki, Dydaktyka dla nauczycieli. Wyd.Adam Marszałek, Toruń.

Prauzner, T. (2010). Applications of multimedia devices as teaching aids, Annales UMCS Informatica AI X, 1(2010).

Prauzner, T. (2013). Information Technology in Contemporary Education - Individuals' Researche. American Journal of Educational Research, 1(10).

Prauzner, T. (2015a). Analysis of the results of the pedagogical research and EEG in the aspect of effective modern teaching aids in the technical education. Society. Integration. Education., Proceedings of the International Scientific Conference. Volume IV. DOI: http://dx.doi.org/10.17770/sie2015vol4.414

Prauzner, T. (2015b). Finite Element Method in an analysis of selected parameters of an inductive sensor for protective coatings measurements, Przeglad Elektrotechniczny, R. 91 NR 12/2015.

Prauzner, T. (2016a). Interactive computer simulation as a response to contemporary problems of technical education. Society. Integration. Education., Proceedings of the International Scientific Conference, Volume II. DOI: http://dx.doi.org/10.17770/sie2016vol2.1415

Prauzner, T. (2016b). Dydaktyczne uwarunkowania rozwijania samodzielnego myślenia $i$ działania studentów $w$ kształceniu technicznym. Wydawnictwo im. Stanisława Podobińskiego Akademii im. Jana Długosza w Częstochowie.

Prauzner, T. (2017a). Innowacyjność kształcenia z wykorzystaniem symulacji interaktywnych $\mathrm{w}$ aspekcie przygotowania człowieka do funkcjonowania $\mathrm{w}$ obecnej rzeczywistości, Problemy Profesjologii, NR 1/2017.

Prauzner, T. (2017b). The effectiveness of school education - featured implications considerations. Society. Integration. Education., Proceedings of the International Scientific Conference, Volume III. DOI: http://dx.doi.org/10.17770/sie2017vol3.2434

Prauzner, T. (2018). Cognitive mechanisms in the didactics of technical vocational subjects in the light of research on bioelectrical brain activity. Society. Integration. Education., Proceedings of the International Scientific Conference, Volume I. DOI: http://dx.doi.org/10.17770/sie2018vol1.3104

Prauzner, T., Prauzner, M., Prauzner, K., \& Ptak, P. (2019). Cognitive activity in the respect of qeeg research - presentation of laboratory tests. Society. Integration. Education., Proceedings of the International Scientific Conference, Volume V. DOI: http://dx.doi.org/10.17770/sie2019vol5.3682 
Prauzner, T., Prauzner, M., \& Prauzner, K. (2018). Ocena aktywności poznawczej w ujęciu aktualnych badań QEEG. Edukacja - Technika - Informatyka, Kwartalnik Naukowy NR 3/25/2018.

Prensky, M. (2001). Digital Game-Based Learning. Saint Paul: Paragon House.

Ptak, P. (2016). Application of software packages in research and didactics. Society, Integration, Education., Proceedings of the International Scientific Conference, Volume II. DOI: http://dx.doi.org/10.17770/sie2017vol3.2436

Ptak, P., \& Prauzner, T. (2019). The use of modern information technology in teaching electronics. Society. Integration. Education., Proceedings of the International Scientific Conference, Volume V. DOI: http://dx.doi.org/10.17770/sie2019vol5.3937

Rubacha, K. (2004). Budowanie teorii pedagogicznych. In Pedagogika. Podręcznik akademicki, Z. Kwieciński, B. Śliwerski (red.), Wyd. PWN, Warszawa.

Zaczyński, W. (1993). Proces kształcenia, Encyklopedia pedagogiczna. Fundacja Innowacja, Warszawa. 